\title{
Bishydroquinone Renieramycin M Induces Apoptosis of Human Lung Cancer Cells Through a Mitochondria-dependent Pathway
}

\author{
TATCHAKORN PINKHIEN ${ }^{1,3}$, ARNATCHAI MAIUTHED ${ }^{2,3}$, SUPAKARN CHAMNI $^{4,5}$, \\ KHANIT SUWANBORIRUX ${ }^{4,5}$, NAOKI SAITO ${ }^{6}$ and PITHI CHANVORACHOTE ${ }^{2,3}$ \\ ${ }^{1}$ Pharmaceutical Technology (International) Program, ${ }^{2}$ Department of Pharmacology and Physiology, \\ ${ }^{3}$ Cell-Based Drug and Health Product Development Research Unit, \\ ${ }^{4}$ Department of Pharmacognosy and Pharmaceutical Botany, \\ ${ }^{5}$ Center for Bioactive Natural Products from Marine Organisms and Endophytic Fungi, \\ Faculty of Pharmaceutical Sciences, Chulalongkorn University, Bangkok, Thailand; \\ ${ }^{6}$ Department of Pharmaceutical Chemistry, Graduate School of Pharmaceutical Sciences, \\ Meiji Pharmaceutical University, Tokyo, Japan
}

\begin{abstract}
Background: Renieranycin M(RM), a bistetrahydroisoquinolinequinone isolated from the Thai blue sponge, Xestospongia sp. was reported to be a potent anti-lung cancer agent. Modification at quinone ring enhanced apoptosis over necrosis. Thus, bishydroquinone renieramycin M(HQ-RM) was prepared and evaluated for apoptosis induction in lung cancer cells. Methods: HQ-RM was examined for cytotoxicity and apoptosis induction in human lung cancer H292 cells by 3-[4,5dimethylthiazol-2-yl]-2,5 diphenyltetrazoliumbromide and Hoechst/propidium iodide staining, respectively. The key molecular markers of mitochondrial apoptosis pathway were determined by western blot analysis. Results: HQ-RM exhibited stronger cytotoxicity than RM. HQ-RM reduced vitality of lung cancer cells in a dose-dependent manner. Nuclear staining assay indicated that apoptotic cell death was the main mechanism of toxicity caused by HQ-RM. Protein analysis revealed that $H Q-R M$-mediated apoptosis involved the increase of pro-apoptotic B-cell lymphoma 2 associated $X(B A X)$ protein, and the decrease of anti-apoptosis myeloid cell leukemia 1 (MCL1) and B-cell lymphoma 2 (BCL2) proteins. Moreover, caspase-9 and -3 and Poly (ADP-ribose) polymerase (PARP) were dramatically cleaved in response to HQ-RM treatment. Conclusion: HQ-RM has highly potent anticancer activity,
\end{abstract}

Correspondence to: Pithi Chanvorachote, Department of Pharmacology and Physiology, Faculty of Pharmaceutical Sciences, Chulalongkorn University, Bangkok, Thailand. Tel: +66 22188285, Fax: +66 22188340, e-mail: pithi_chan@yahoo.com

Key Words: Renieramycin M, bishydroquinone renieramycin $\mathrm{M}$, apoptosis, lung cancer, BCL2. greater than its parental RM, and induces lung cancer cell apoptosis through a mitochondrial apoptosis caspase-dependent mechanism. This information benefits the development of this compound for cancer therapy.

Due to the problem of drug resistance frequently found in patients with lung cancer, a much research is currently focused on novel drug discovery and efficacy testing $(1,2)$. Marine organisms have been documented as important sources of bioactive anticancer compounds. Renieramycins are a group of tetrahydroisoquinoline marine natural products which are structurally and biologically related to saframycins, naphthyridinomycins, quinocarcins, and ecteinascidins (3). Previously, we described anticancer and anti-metastatic activities of renieramycin M (RM), a bioactive compound isolated from a Thai blue sponge, Xestospongia sp. (4); however, its low solubility has limited its further development.

Renieramycin M (Figure 1) and other renieramycins have been shown to possess promising cytotoxicity, with $50 \%$ inhibitory concentration $\left(\mathrm{IC}_{50}\right)$ values in the range of nanomolar against HCT116 human colon, DLD1 human colon, QC56 human lung, NCI-H460 human non-small cell lung, MDA-MB-435 breast, T47D human ductal breast epithelial, and AsPC1 human pancreatic cancer cell lines (58). Interestingly, reduction of the quinone moiety at the lefthanded side of the core structure followed by acetylation of C-5 position selectively controlled the cancer cell death mechanism through apoptosis without necrosis (8).

Herein, bishydroquinone renieramycin M (HQ-RM) (Figure 1) was prepared from hydrogenation of RM with $20 \% \mathrm{Pd}(\mathrm{OH})_{2} / \mathrm{C}(8)$. The present study aimed to elucidate 


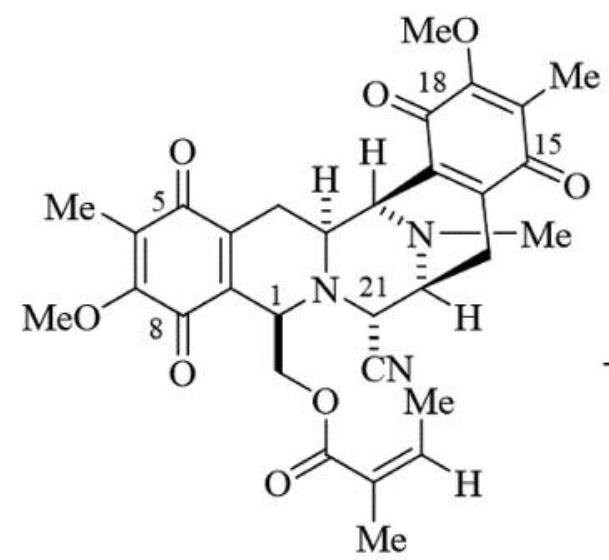

RM

\section{$\mathrm{H}_{2}, 20 \% \mathrm{Pd}(\mathrm{OH})_{2} / \mathrm{C}$}

EtOAc, rt, $1 \mathrm{~h}$, quant.

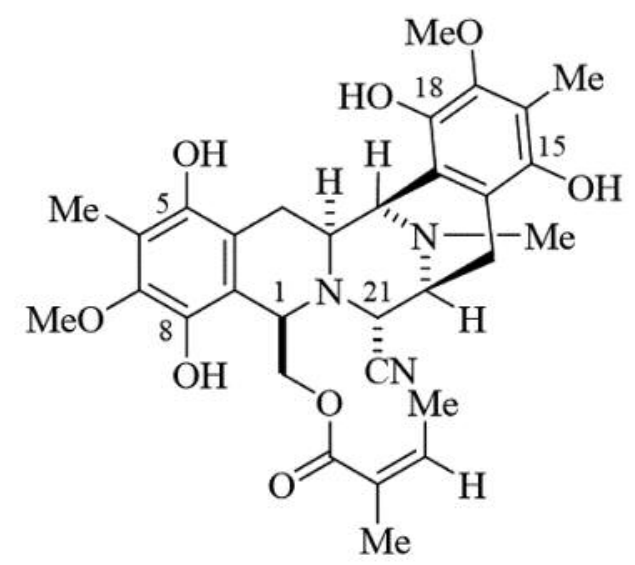

HQ-RM

Figure 1. The synthesis of bishydroquinone renieramycin $M(H Q-R M)$. Hydrogenation of renieramycin $M(R M)$ with $20 \%$ Pd $(\mathrm{OH})_{2} / C$ in ethyl acetate for $1 \mathrm{~h}$ gave the colorless luco compound HQ-RM.

apoptosis-inducing effect and the underlying mechanism of action HQ-RM against lung cancer cells.

\section{Materials and Methods}

Materials. Human non-small cell lung cancer cells (H292) were purchased from the American Type Culture Collection (Manassas, VA, USA). Penicillin, streptomycin, glutamate, and phosphatebuffered saline (PBS) were purchased from GIBCO (Grand Island, NY, USA). Methanol, ethanol and dimethyl sulfoxide (DMSO) were purchased from Sigma-Aldrich (St. Louis, MO, USA). Antibodies to caspase-3, caspase-9, Poly (ADP-ribose) polymerase (PARP), Bcell lymphoma 2 associated $\mathrm{X}$ (BAX) protein, Myeloid cell leukemia 1 (MCL1) and B-cell lymphoma 2 (BCL2) were from Cell Signaling Technology, Inc. (Danvers, MA, USA). RM was extracted from Thai blue sponge, Xestospongia sp. and HQ-RM was prepared from $\mathrm{RM}$ by $\mathrm{Pd}(\mathrm{OH})_{2} / \mathrm{C}$ catalyzed hydrogenation (8).

Cell culture conditions. H292 was cultured with Roswell Park Memorial Institute 1640 medium supplemented with $10 \%$ fetal bovine serum (FBS), $2 \mathrm{mM}$ L-glutamine and $100 \mathrm{units} / \mathrm{ml}$ penicillin and streptomycin at $37^{\circ} \mathrm{C}$ in a humidified atmosphere of $5 \% \mathrm{CO}_{2}$. Cells were seeded as recommended by the supplier and split at $70 \%$ confluence.

Cell viability assay. The 3-[4,5-dimethylthiazol-2-yl]-2,5 diphenyltetrazoliumbromide (MTT) assay was performed to determine the effect of HQ-RM and RM on the cellular viability of H292 cells. Briefly, approximately $1 \times 10^{4}$ cells/well were plated in 96-well plates and kept in an incubator at $37^{\circ} \mathrm{C}$ under the previously described cell culture conditions. After overnight incubation to allow them to adhere, the cells were treated with different concentrations of HQ$\mathrm{RM}$ and $\mathrm{RM}(0.5 \mu \mathrm{M}$ to $100 \mu \mathrm{M})$ in fresh medium for $24 \mathrm{~h}$. Each treatment at this time point was assayed in at least triplicate. At the stipulated time following treatment with HQ-RM or RM, the medium was aspirated and MTT ( $4 \mathrm{mg} / \mathrm{ml}$ stock solution in $1 \times \mathrm{PBS})$ was added to each well of the 96-well culture plate. Incubation was continued at $37^{\circ} \mathrm{C}$ for an additional $4 \mathrm{~h}$, then supernatants were discarded, and purple-colored precipitates of formazan were dissolved in $100 \mathrm{ml}$ of DMSO. The color absorbance of each aliquot was recorded at $570 \mathrm{~nm}$ with a microplate reader and repeated three times. The cytotoxic effect was expressed as the percentage cell viability compared to that of non-treated cells.

Nuclear staining assay. $\mathrm{H} 292$ cells were seeded in 96-well plates at a density of $1 \times 10^{4}$ cells/well, incubated overnight, and treated with HQ-RM $(15,30$ and $60 \mu \mathrm{M})$ for $12 \mathrm{~h}$. Next, the cells were rinsed in PBS and subsequently incubated with $10 \mu \mathrm{g} / \mathrm{ml}$ Hoechst 33342 and $5 \mu \mathrm{g} / \mathrm{ml}$ propidium iodide for $30 \mathrm{~min}$. Nuclear condensation and DNA fragmentation of apoptotic cells and propidium iodide-positive necrotic cells were visualized and scored using a fluorescence microscope (Olympus IX5; ×40) equipped with a DP70 digital camera system (Olympus, Tokyo, Japan).

Western blot analysis. Proteolytic cleavage of pro-apoptotic proteins and pro-apoptotic proteins were detected by western blot analysis. $\mathrm{H} 292$ cells were treated with 15,30 and $60 \mu \mathrm{M}$ of HQ-RM for $12 \mathrm{~h}$ and harvested. All cells were collected by scraping and were lysed with lysis buffer for $45 \mathrm{~min}$. The protein concentrations were measured with the Pierce ${ }^{\mathrm{TM}}$ BCA Protein Assay Kit (Pierce, Rockford, IL, USA). The resultant lysates were boiled at $95^{\circ} \mathrm{C}$ for 5 min with Laemmli loading buffer and were subsequently loaded onto a $10 \%$ SDS-polyacrylamide gel. After separation, the proteins were transferred to nitrocellulose membrane (Bio-Rad, Hercules, CA, USA). The membranes were blocked for $1 \mathrm{~h}$ in $5 \%$ nonfat dry milk in TBST (25 mM Tris-HCl (pH 7.5), $125 \mathrm{mM} \mathrm{NaCl}$ and $0.05 \%$ Tween 20) and incubated overnight with the appropriate primary antibodies at $4^{\circ} \mathrm{C}$. The membranes were washed twice with TBST for $10 \mathrm{~min}$ and incubated with horseradish peroxidasecoupled isotype-specific secondary antibodies for $1 \mathrm{~h}$ at room temperature. The immune complexes were detected by enhancement with a chemiluminescence substrate (Pierce) and quantified using analyst/PC densitometry software (Bio-Rad). 


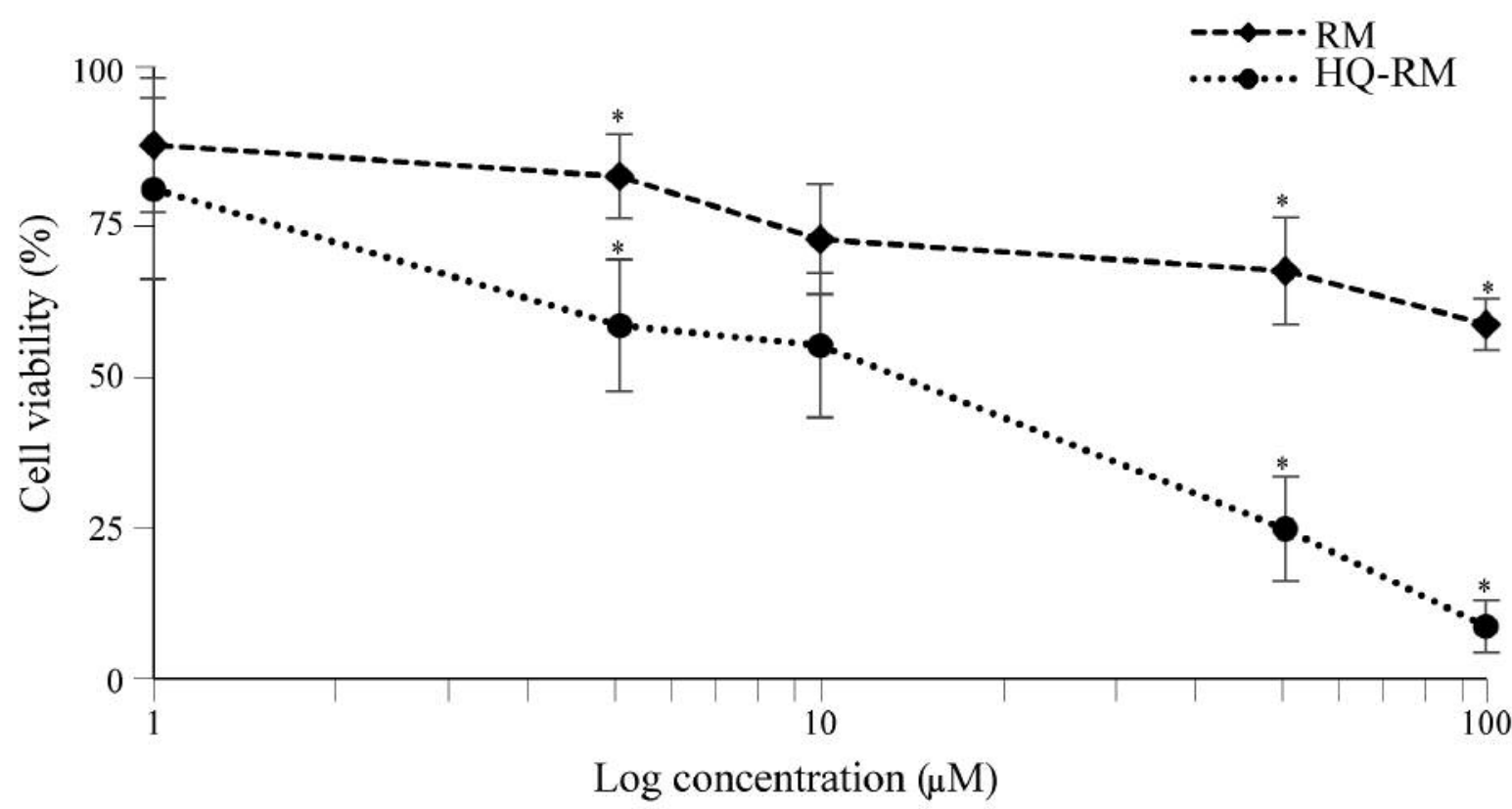

Figure 2. Cytotoxic effect of bishydroquinone renieramycin M (HQ-RM). H292 Human non-small cell lung cancer cells were treated with HQ-RM $(0-100 \mu M)$ for 24 h. Cell viability was analyzed by 3-[4,5-dimethylthiazol-2-yl]-2,5 diphenyltetrazoliumbromide assay. Data represent the mean \pm SD $(n=3) . * p<0.05$ versus renieramycin $M(R M)$.

Statistical analysis. Data from three or more independent experiments are presented as the mean \pm standard deviation (SD). Multiple comparisons for significant differences between multiple groups were performed using analysis of variance (ANOVA), followed by individual comparisons with Scheffe's post-hoc test. Statistical significance was considered at $p<0.05$.

\section{Results}

Cytotoxicity evaluation. The anticancer activity of HQ-RM and its parental compound RM were evaluated in human lung cancer H292 cells by MTT assay. Cells were treated with the compounds over a range of concentrations between $0.5 \mu \mathrm{M}$ and $100 \mu \mathrm{M}$ for $24 \mathrm{~h}$. Cell viability was determined and is shown in Figure 2.

HQ-RM was found to be more potent than RM as it had a lower $\mathrm{IC}_{50}$ than $\mathrm{RM}(\mathrm{n}=3)$. In order to further investigate the mode of cell death, the occurrence of apoptotic and necrotic cells was determined by nuclear staining. After $24 \mathrm{~h}$ of treatment, cells were incubated with Hoechst 33342 and propidium iodide and subsequently analyzed by fluorescence microscopy as shown in Figure 3. The control or untreated cells appeared to be intact with oval shape nuclei stained with a less bright blue fluorescence. However, the decrease in cell viability in response to HQ-RM treatment was mainly due to apoptosis (reflected by bright dots in Figure 3), as determined by the increase in number of cells with intense nuclear fluorescence and chromatin condensation. Approximately $\sim 9 \%$ apoptosis was detected at a concentration of $0.05 \mu \mathrm{M}$ $\mathrm{RM}$ and this reached $\sim 90 \%$ at a concentration of $100 \mu \mathrm{M}$ of HQ-RM. The results from propidium iodide staining show that HQ-RM induced necrosis at high concentrations (50 and $100 \mu \mathrm{M}$ ) (Figure 3).

In order to evaluate the cytotoxicity of HQ-RM, the cells were collected after 12-h treatment with HQ-RM and the dead cells were quantified by TC20 ${ }^{\mathrm{TM}}$ Automated Cell Counter. The results indicate increasing death of cells in response to increasing HQ-RM concentration from imagebased cytometry (Figure 4).

HQ-RM induced apoptosis via mitochondrial pathway. Having shown that HQ-RM mediated lung cancer cell death via apoptosis, we next investigated the mechanism of such an apoptosis induction. The effect of HQ-RM on apoptosisrelated proteins was determined by western blot analysis. Cells were treated with HQ-RM $(0-60 \mu \mathrm{M})$ and the pro-and anti-apoptotic protein of BCL2 family proteins, and the cleavage and total forms of caspase 3 and -9 , and PARP were evaluated after $12 \mathrm{~h}$. Anti-apoptotic MCL1 and BCL2 proteins were down-regulated, while the expression of proapoptotic BAX protein was significantly up-regulated (Figure 5). The mitochondrial specific caspase-9 was found to be activated after HQ-RM treatment. Furthermore, the executive caspase-3, caspase-9 and PARP were found to be activated in HQ-RM-treated cells. Taken together, these 


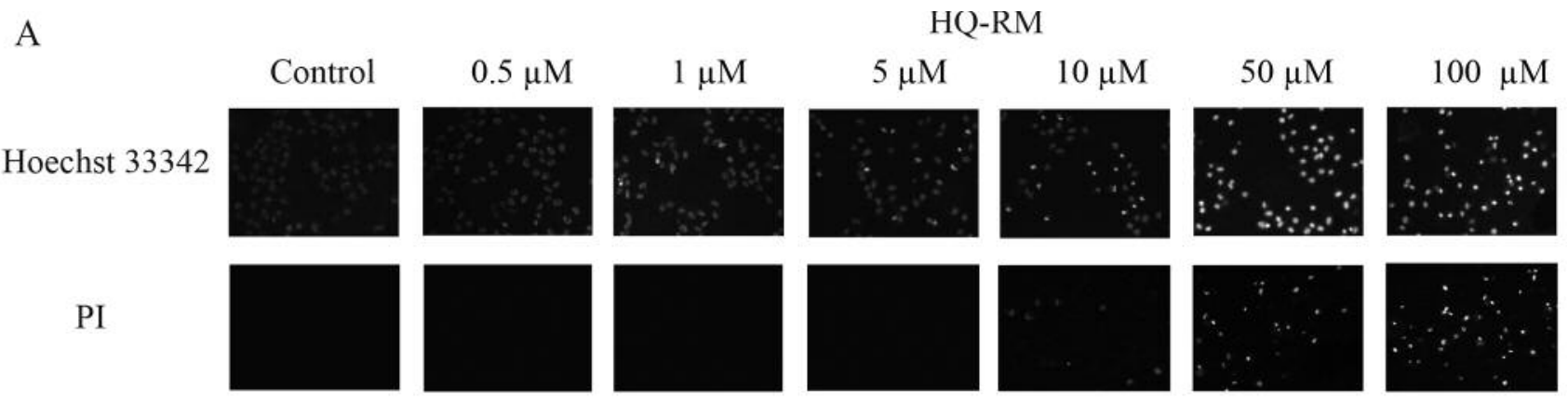

B

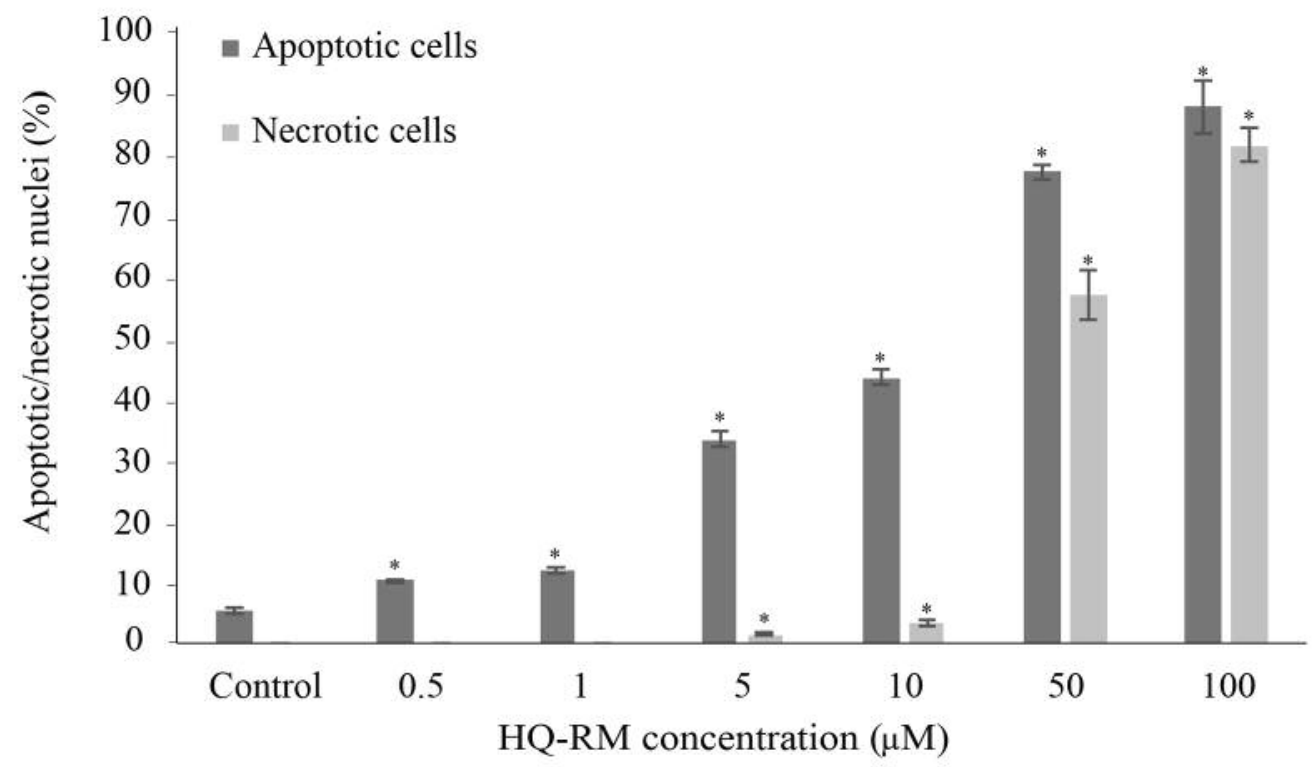

Figure 3. Apoptosis and necrosis inducing effects of bishydroquinone renieramycin $M(H Q-R M)$. Cells were treated with HQ-RM at different concentrations for 24 h. A: Apoptotic and necrotic cell death after HQ-RM treatment were examined by Hoechst 33342/propidium iodide (PI) co-staining. B: Percentage of apoptotic and necrotic nuclei in HQ-RM-treated cells. Data represent the mean $\pm S D(n=3)$. ${ }^{*} p<0.05$ versus non-treated control.

results indicate that HQ-RM mediates lung cancer apoptosis by increasing the ratio of pro-apoptotic/antiapoptotic proteins and activating the mitochondrial apoptosis pathway.

\section{Discussion}

The need for more effective chemotherapy is increasing each year, as the estimated number of patients with lung cancer continuously rises. More than $25 \%$ of drugs used during the last 20 years were developed directly from natural products, while the other $25 \%$ are chemically derived natural products (9). Based on the data gathered from this study, HQ-RM appears to be more cytotoxic than its parental RM (Figure 2). HQ-RM was shown herein to mediate cell death through apoptosis. Indeed, apoptosis induction is an important cell death mechanism by which most cytotoxic drugs destroy cancer cells. Apoptosis can be triggered by two major pathways: the death receptor and mitochondrial pathways (10). While the death receptor pathway is mainly caused by the activity of immune cells, anticancer agents trigger mitochondrial pathway mediated apoptosis. As shown in Figure 6, the mechanism of action of HQ-RM is via the reduction of anti-apoptotic BCL2 and MCL1 proteins, and the increase of pro-apoptotic BAX protein. This altered balance of BCL2 family members initiates the release of mitochondrial substances and activates caspase- $9(11,12)$. 


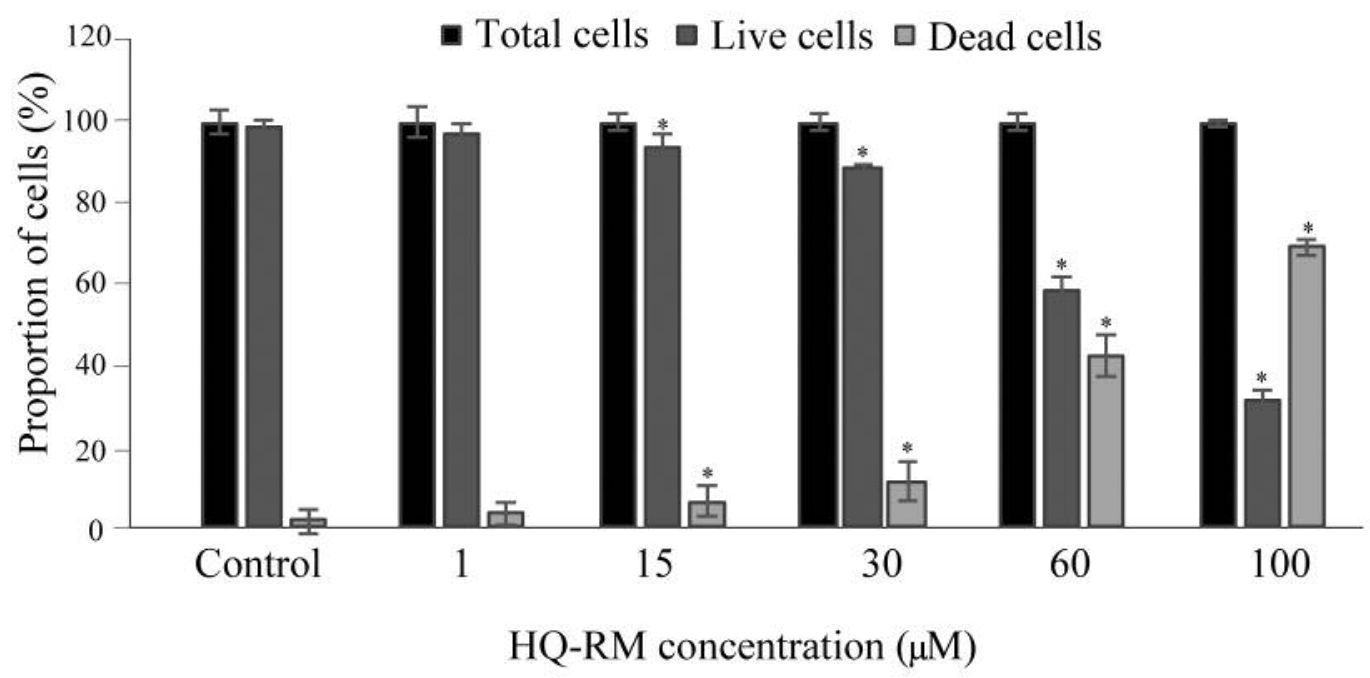

Figure 4. Analysis of cell death. H292 cells were treated with different concentrations bishydroquinone renieramycin M (HQ-RM) for 12 h. Cell death was quantified by TC2O $0^{T M}$ Automated Cell Counter.

A

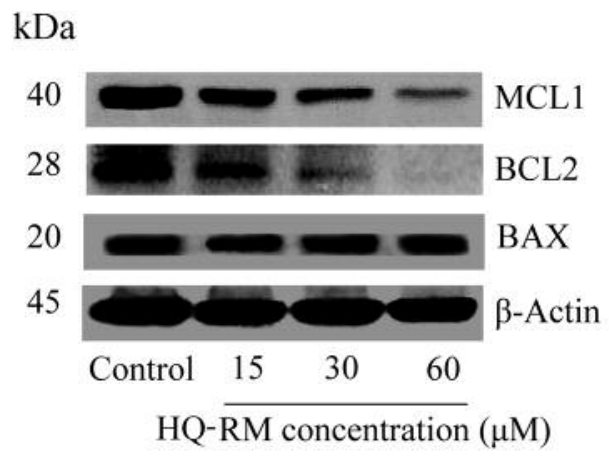

$\mathrm{kDa}$
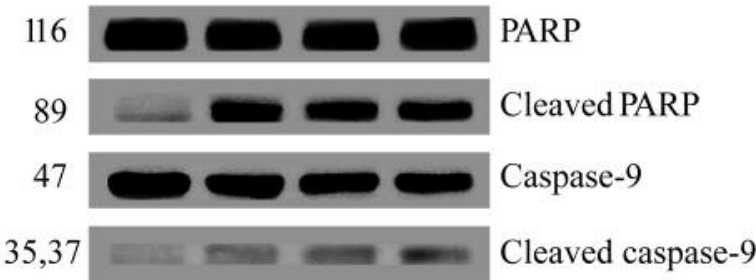

32

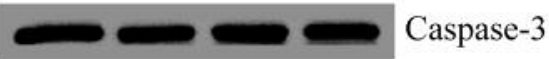

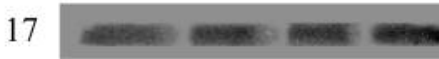

45

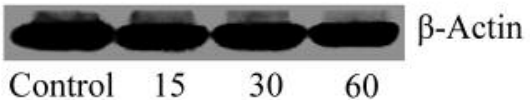

HQ-RM concentration $(\mu \mathrm{M})$

B
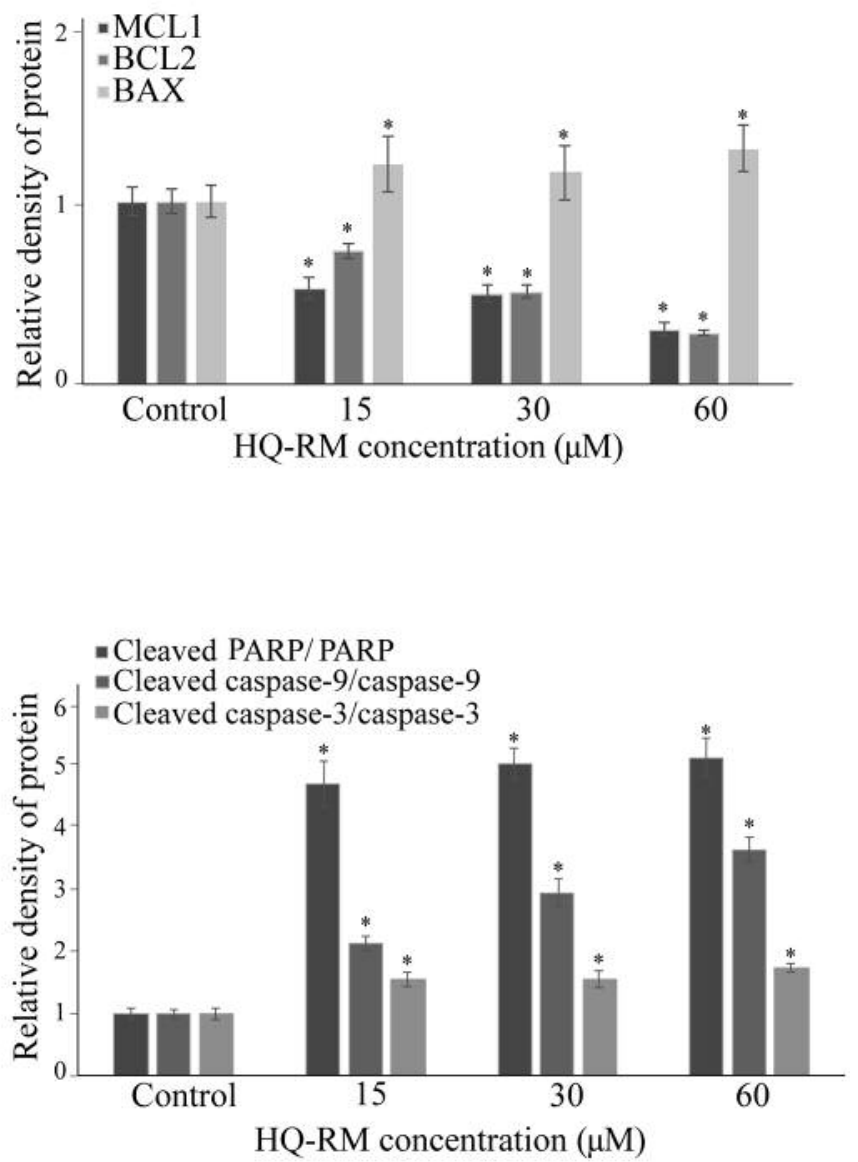

Figure 5. Evaluation of mitochondrial apoptosis proteins. $H 292$ cells were treated with bishydroquinone renieramycin M (HQ-RM) for 12 h. The expression levels of anti-apoptotic proteins and pro-apoptotic proteins in $\mathrm{H} 292$ cells were determined by western blotting (A) and relative protein levels were quantified by densitometry $(B)$. Data represent mean $\pm S D(n=3) .{ }^{*} p<0.05$ versus non-treated control. MCL1: Myeloid cell leukemia 1; BCL2: B-cell lymphoma 2; BAX: B-cell lymphoma 2 associated X; PARP: Poly (ADP-ribose) polymerase. 


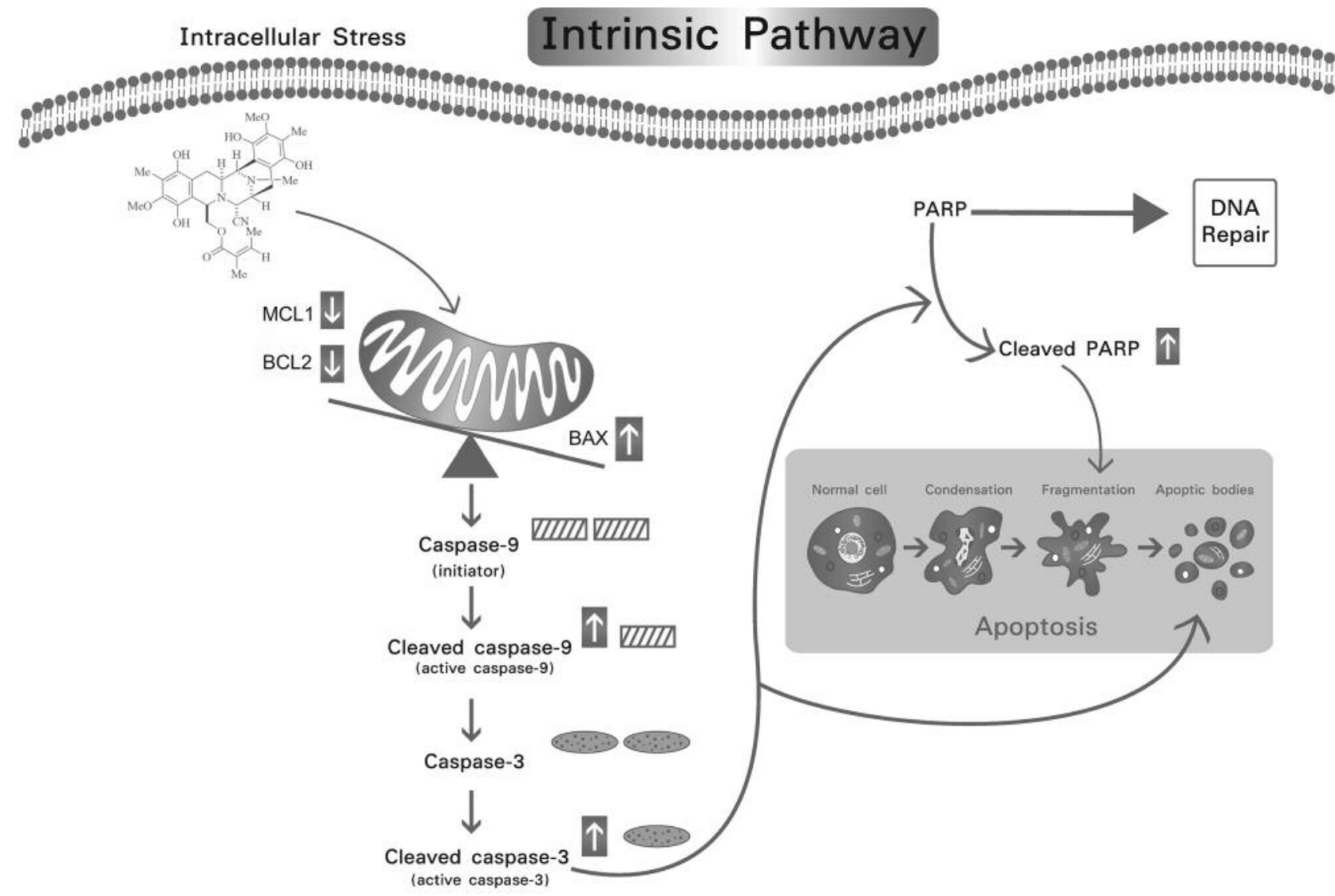

Figure 6. Schematic overview of apoptosis pathway of bishydroquinone renieramycin M (HQ-RM) action. HQ-RM causes apoptosis by decreasing the anti-apoptotic member of the B-cell lymphoma 2 (BCL2) family, namely BCL2 and Myeloid cell leukemia 1 (MCL1), and increasing the proapoptotic B-cell lymphoma 2 associated X $(B A X)$ protein. The balance between pro-and anti-apoptotic BCL2 family members shifts toward increased pro-apoptotic proteins, then the caspase cascade is activated and results in cell apoptosis. PARP: Poly (ADP-ribose) polymerase.

Many cancer cells depend upon BCL2 and other antiapoptotic proteins for their survival. Several BCL2 antagonists such as ABT-263, Obatoclax, and Oblimersen, are currently under evaluation in the clinical phase for the treatment of lung cancer (13). Publications on cell death show that members of the BCL2 family such as BCL2, MCL1 and BAX, are major regulators of cell survival. MCL1, an important anti-apoptotic member of the BCL2 family, is one of the most frequently overexpressed anti-apoptotic genes in human cancer. The overexpression of MCL1 in cancer cells is implicated in resistance to multiple cancer therapies (14). Moreover, drug resistance in cancer was associated with an increased level of BCL2 and MCL1 (15). Thus, HQ-RM potentially targets these proteins and may not only induce apoptosis but also benefit the therapeutic strategy by overcoming drug-resistant cancer cells.

The caspases are a family of cysteine proteases whose main function is the central regulation of cell death. In our study, the cleavage of caspase-3, caspase-9 and PARP were significantly increased in HQ-RM-treated cells. When activated, caspase-9 in this complex activates caspase- 3 to execute apoptosis (16). Caspase- 3 then cleaves key substrates in the cell to produce many of the cellular and biochemical events of apoptosis. In addition, the activated caspases play a key role in the execution of the apoptotic program, including the cleavage of PARP during cell death to prevent the cells from repairing DNA (17).

Previous studies have shown that RM is a potential antimetastatic agent by sensitizing lung cancer cells to anoikis by the suppression of anoikis-resistance mechanisms (18). Moreover, RM was shown to induce lung cancer cell apoptosis through the p53-dependent pathway (4). RM and derivatives exhibited anticancer activity against human colonic carcinoma (HCT116) and human lung carcinoma (QG56) cells (8). Moreover, 5-O-acetylated hydroquinone derivative of RM was reported to have a beneficial activity by causing low degree of necrosis (19). Our studies are in agreement with such reports that RM and its derivative are good candidates for further development and further provide evidence for the promising activity of HQ-RM in apoptosis induction (Figure 6). 


\section{Conclusion}

Our results demonstrate that HQ-RM, a newly-synthesized RM derivative, exhibits potent anticancer activity against H292 lung cancer cells. HQ-RM appears to induce apoptosis by suppressing expression of anti-apoptotic BCL2 and MCL1 and increasing that of pro-apoptotic BAX. The altered balance of BCL2 family proteins leads to the activation of caspase-3 and -9 and ultimately to apoptosis (Figure 6). Understanding the mechanism of action of this compound may benefit its further development for anticancer approaches.

\section{Conflicts of Interest}

The Authors declare there is no conflict of interest with regard to this study.

\section{Acknowledgements}

This study was supported by a grant for International Research Integration: Chula Research Scholar, Ratchadaphiseksomphot Endowment Fund.

\section{References}

1 Ma X and Yu H: Global Burden of Cancer. Yale J Biol Med 79: 85-94, 2006.

2 Zhang W, Lei P, Dong X and Xu C: The new concepts on overcoming drug resistance in lung cancer. Drug Des Devel Ther 8: 735-744, 2014.

3 Scott JD and Williams RM: Chemistry and biology of the tetrahydroisoquinoline antitumor antibiotics. Chem Rev 102: 1669-1730, 2002.

4 Halim H, Chunhacha P, Suwanborirux K and Chanvorachote P: Anticancer and antimetastatic activities of renieramycin $\mathrm{M}$, a marine tetrahydroisoquinoline alkaloid, in human non-small cell lung cancer cells. Anticancer Res 31: 193-201, 2011.

5 Saito N, Tanaka C, Koizumi Y-i, Suwanborirux K, Amnuoypol S, Pummangura S and Kubo A: Chemistry of renieramycins. Part 6: Transformation of renieramycin $\mathrm{M}$ into jorumycin and renieramycin $\mathrm{J}$ including oxidative degradation products, mimosamycin, renierone and renierol acetate. Tetrahedron 60 : 3873-3881, 2004.

6 Charupant K, Suwanborirux K, Amnuoypol S, Saito E, Kubo A and Saito N: Jorunnamycins A-C, new stabilized renieramycintype bistetrahydroisoquinolines isolated from the Thai nudibranch Jorunna funebris. Chem Pharm Bull 55: 81-86, 2007.

7 Charupant K, Daikuhara N, Saito E, Amnuoypol S, Suwanborirux K, Owa T and Saito N: Chemistry of renieramycins. Part 8: synthesis and cytotoxicity evaluation of renieramycin M-jorunnamycin A analogues. Bioorg Med Chem 17: 4548-4558, 2009.
8 Amnuoypol S, Suwanborirux K, Pummangura S, Kubo A, Tanaka $\mathrm{C}$ and Saito N: Chemistry of renieramycins. Part 5. Structure elucidation of renieramycin-type derivatives $\mathrm{O}, \mathrm{Q}, \mathrm{R}$ and $\mathrm{S}$ from Thai marine sponge Xertospongia species pretreated with potassium cyanide. J Nat Prod 67: 1023-1028, 2004.

9 Vuorelaa P, Leinonenb M, Saikkuc P, Tammelaa P, Rauhad JP, Wennberge $\mathrm{T}$ and Vuorela $\mathrm{H}$ : Natural products in the process of finding new drug candidates. Curr Med Chem 11: 1375-1389, 2004.

10 Czabotar PE, Lessene G, Strasser A and Adams JM: Control of apoptosis by the BCL-2 protein family: implications for physiology and therapy. Nat Rev Mol Cell Biol 15: 49-63, 2014.

11 Marsden VS, O'Connor L, O'Reilly LA, Silke J, Metcalf D, Ekert PG, Huang DCS, Cecconi F, Kuida K, Tomaselli KJ, Roy S, Nicholson DW, Vaux DL, Bouillet P, Adams JM and Strasser A: Apoptosis initiated by Bcl-2-regulated caspase activation independently of the cytochrome c/Apaf-1/caspase-9 apoptosome. Nature 419: 634-637, 2002.

12 Wang C and Youle RJ: The Role of Mitochondria in Apoptosis. Annu Rev Genet 43: 95-118, 2009.

13 Brunelle JK and Letai A: Control of mitochondrial apoptosis by the Bcl-2 family. J Cell Sci 122: 437-441, 2009.

14 Abdel-Magid AF: Inhibitors of the antiapoptotic myeloid cell leukemia-1 (MCL-1) may provide effective treatment for cancer. ACS Med Chem Lett 6: 1171-1173, 2015.

15 Wesarg E, Hoffarth S, Wiewrodt R, Kroll M, Biesterfeld S, Huber C and Schuler M: Targeting BCL-2 family proteins to overcome drug resistance in non-small cell lung cancer. Int $\mathrm{J}$ Cancer 121: 2387-2394, 2007.

16 Sanmartín C, Plano D, Sharma AK and Palop JA: Selenium compounds, apoptosis and other types of cell death: an overview for cancer therapy. Int J Mol Sci 13: 9649-9672, 2012.

17 Chaitanya GV, Alexander JS and Babu PP: PARP-1 cleavage fragments: signatures of cell-death proteases in neurodegeneration. Cell Commun Signal 8: 31-31, 2010.

18 Sirimangkalakitti N, Chamni S, Suwanborirux K and Chanvorachote P: Renieramycin M sensitizes anoikis-resistant H460 lung cancer cells to anoikis. Anticancer Res 36: 1665$1671,2016$.

19 Cheun-Arom T, Chanvorachote P, Sirimangkalakitti N, Chuanasa T, Saito N, Abe I and Suwanborirux K: Replacement of a quinone by a $5-O$-acetylhydroquinone abolishes the accidental necrosis-inducing effect while preserving the apoptosis-inducing effect of renieramycin $\mathrm{M}$ on lung cancer cells. J Nat Prod 76: 1468-1474, 2013.
Received September 26, 2016

Revised October 18, 2016

Accepted October 28, 2016 